\title{
Effects of Gypsum on Zoospores and Sporangia of Phytophthora cinnamomi in Field Soil
}

\author{
B. J. Messenger, J. A. Menge, and E. Pond, Department of Plant Pathology, University of California, Riverside \\ 92521
}

\begin{abstract}
Messenger, B. J., Menge, J. A., and Pond, E. 2000. Effects of gypsum on zoospores and sporangia of Phytophthora cinnamomi in field soil. Plant Dis. 84:617-621.

Sporangial production of Phytophthora cinnamomi buried in gypsum-amended avocado soil for 2 days was reduced by as much as $74 \%$ in greenhouse trials. P. cinnamomi sporangial volume was reduced an average of $64 \%$ in gypsum-amended soil. Soil extracts from gypsum-amended soil reduced in vitro sporangial production and volume. Irrigation with gypsum solutions of buried mycelium in unamended soil also reduced sporangial production and volume. Zoospore production and colony-forming units of $P$. cinnamomi were reduced in soil amended with calcium sulfate, calcium nitrate, or calcium carbonate. Zoospore encystment or passive movement through soil was not significantly affected by gypsum soil amendments.
\end{abstract}

Phytophthora root rot of avocado, caused by Phytophthora cinnamomi Rands, is a serious disease on commercial avocados and the limiting factor in avocado production in California (5). Gypsum $\left(\mathrm{CaSO}_{4} \cdot 2 \mathrm{H}_{2} \mathrm{O}\right)$ soil amendments can decrease the incidence of this disease $(4,18,20)$. Mechanisms for decrease in disease incidence could be related to a decrease in the pathogen inoculum level caused by high levels of calcium sulfate. Calcium ions in an axenic solution have profound effects on the asexual reproduction of $P$. cinnamomi, specifically, sporangial production (12), zoospore motility (6), zoospore encystment (13), and zoospore adhesion (11).

Calcium sulfate in an ionic, axenic solution reduces sporangial production of Phytophthora spp. (12). The motility of zoospores of Pythium is severely perturbed by the addition of $5 \mathrm{mM}$ ionic calcium to the zoospore suspension. The zoospores swim in circles instead of the normal spiraling swimming pattern and are unable to respond to an attractant amino acid (6). This disruption in zoospore behavior, if it occurs in high-calcium soil, should cause the zoospores to be unable to swim to the host root. A moderate level of ionic calcium is required for membrane stability, however, and restricting calcium to below $0.1 \mu \mathrm{M}$ destabilizes the cell membrane,

Corresponding author: B. J. Messenger

E-mail: bmessenger@agraquest.com

Current address of B. J. Messenger: AgraQuest, Inc., 1530 Drew Avenue, Davis, CA 95616.

Accepted for publication 15 February 2000.

Publication no. D-2000-0417-02R

(c) 2000 The American Phytopathological Society causing lysis of the zoospore $(8,10)$. Addition of high levels $(30 \mathrm{mM})$ of ionic calcium causes immediate encystment of all zoospores in the solution, which is rapidly followed by germination of the encysted zoospores $(3,13)$. Calcium is also essential in adhesion of encysted zoospores to the host tissue (11). Calcium is excreted from the cyst following encystment and appears to activate the compound responsible for adhesion. The adhesive compound is not specific to plant material; cysts can adhere to glass and other inorganic substances (11). Zoospores in soil that prematurely encyst and secrete this adhesive compound will be less likely to infect a host root. These previous studies were all conducted in sterile solutions under laboratory conditions, and the behavior of zoospores in soil or in a nonsterile solution is little known under high-calcium conditions. Factors such as soil texture and structure, effect of other microorganisms on the pathogen, and altered soil infiltration conditions can modulate the effect of calcium ions in soil.

In one nonaxenic study, addition of calcium to soil was shown to decrease sporangial production and zoospore release (15); however, the study focused mainly on calcium nitrate, and sporangial dimensions were not measured, nor was zoospore production, encystment, or motility. The number of zoospores that reach and infect the avocado root is directly affected by zoospore production, sporangial dimensions, encystment, and motility. This study examines the effects of gypsum-amended field soil on sporangial production and dimensions, zoospore production, encystment, and motility in order to explain why gypsum soil amendments affect Phytophthora root rot. It also attempts to elucidate whether the effects are caused by soil structure differences in gypsum-amended soil, or whether the aqueous extract from gypsum-amended soil or irrigation with a gypsum solution would duplicate the effects, indicating a calcium ion effect.

\section{MATERIALS AND METHODS}

Soil. The soil used in these studies was a Placentia sandy loam from an avocado grove in Fallbrook, CA. It was uninfested with $P$. cinnamomi and had the following characteristics: $\mathrm{pH}$ (saturated paste) 6.8; electrical conductivity, $2.51 \mathrm{mS} / \mathrm{cm}$; organic matter, $2.43 \%$; Ca, $17.62 \mathrm{meq} / \mathrm{liter}$. The soil was homogenized by passage through a 2-mm sieve and irrigated three to four times with tap water after placement into pots or petri plates. The amount of free calcium in soil extracts of gypsumamended soils and the unamended soil was determined by atomic absorption spectroscopy (14). The unamended soil contained 1 $\mathrm{mM}$ soluble calcium; the $1 \%$ gypsumamended soil contained $4 \mathrm{mM}$ soluble calcium; and the 5\% gypsum-amended soil and the $10 \%$ gypsum-amended soil both contained $5 \mathrm{mM}$ soluble calcium.

Preparation of fungal propagules. Mycelial mats for sporangial production trials were produced by growing mycelial plugs in clarified half-strength V8 juice broth for 2 to 3 days in the dark. Mats were then rinsed three times with sterile distilled water, placed in a fine nylon mesh inside plastic photographic slide mounts (Pakon, Inc., Minnetonka, MN), and buried in the soil in the sporangial and zoospore production trials. Sporangia were induced using a soil extract method (1) in the zoospore motility and encystment studies. The mats were washed with distilled water and then incubated at $4^{\circ} \mathrm{C}$ for $20 \mathrm{~min}$. Mats were further incubated at $25^{\circ} \mathrm{C}$ for $1 \mathrm{~h}$ until the zoospores released.

Concentration of sporangia. In order to determine the concentration of sporangia, mycelial mats were ground in a Waring Blender for $30 \mathrm{~s}$ at high speed. Sporangia in the resulting slurry were examined using phase-contrast microscopy at $\times 125$. The number of sporangia visible was counted using an eelworm counter (Hawksley, Lansing, England). The percentages of sporangia that were vacuolated, differentiated, or undifferentiated were calculated.

Mean volume of sporangia. The length and width of 10 sporangia per sample were measured with a micrometer and averaged. Mean volume of the 10 sporangia was 
calculated using the formula: Volume = $4 / 3 \pi a b^{2}$, where $a=1 / 2$ length (the long axis) and $b=1 / 2$ width (the short axis).

Enumeration of zoospores. Mycelial mats were treated to induce zoospore release as described above. Zoospores were harvested and quantified microscopically with an eelworm counter (Hawksley). One hundred microliters per sample of the zoospore suspensions were plated onto a modified version of PARPH, a medium selective for Phytophthora spp. (7). The modifications are as follows (per liter of corn meal agar [Difco Laboratories, Detroit, MI]): $10 \mathrm{mg}$ of pimaricin, $250 \mathrm{mg}$ of ampicillin, $10 \mathrm{mg}$ of rifampicin, $100 \mathrm{mg}$ of pentachloronitrobenzene, and $75 \mathrm{mg}$ of hymexazol. The resulting $P$. cinnamomi colonies, representing viable zoospores, were counted after 2 days of growth.

Statistical analyses. Data from each trial were analyzed by analysis of variance with the general linear model (GLM) procedure of the SAS program (SAS Institute, Cary, NC). Separation of means was determined by the Waller-Duncan Bayesian $k$-ratio $t$ test. Data from the repeated trials in each experiment were combined when they showed no statistically significant difference when subjected to an $F$ test.

Frequency and size of sporangia and zoospore production. Two trials of this experiment were conducted on lathhouse benches to determine the effect of gypsum soil amendments on sporangial production, volume, and zoospore production using eight plastic, drained pots (2 liter) per soil treatment. Ambient temperature ranged from 20 to $30^{\circ} \mathrm{C}$, and pots were in partial shade under a concrete awning. Soil was amended with 5\% (wt/wt) gypsum, $10 \%$ (wt/wt) gypsum, or was not amended and was watered daily for 7 days. On day 7, 2day-old mycelial mats of $P$. cinnamomi were buried 2 to $3 \mathrm{~cm}$ below the surface of the soil. The soil was watered to container capacity after the mats were added. The mats were removed from the soil 2 days later and rinsed with sterile distilled water. Sporangial and zoospore production and sporangial dimensions were determined as described above.

The effect of soil extracts of gypsum-

Table 1. Mean volume and number of sporangia per milliliter produced in gypsum-amended and unamended preirrigated field soil in pots ${ }^{\mathrm{x}}$

\begin{tabular}{lcc}
\hline Amendment & $\begin{array}{c}\text { Sporangia } \\
\text { per m } \mathbf{l}^{\mathbf{y}, \mathbf{z}}\end{array}$ & $\begin{array}{c}\text { Sporangial } \\
\text { vol. }^{\mathbf{y}, \mathbf{z}}\left(\boldsymbol{\mu m}^{\mathbf{3}}\right)\end{array}$ \\
\hline Unamended & $649 \mathrm{a}$ & $1.6 \times 10^{5} \mathrm{a}$ \\
$5 \%$ gypsum & $169 \mathrm{~b}$ & $5.1 \times 10^{4} \mathrm{~b}$ \\
$10 \%$ gypsum & $259 \mathrm{~b}$ & $6.2 \times 10^{4} \mathrm{~b}$ \\
\hline
\end{tabular}

${ }^{x}$ This experiment was repeated and the results combined since there was no significant difference between the two experiments.

${ }^{y}$ Values represent the mean of 16 replications.

${ }^{\mathrm{z}}$ Means followed by the same letters are not significantly different according to the Waller Duncan Bayesian $t$ test at $P \leq 0.05$. amended soil on $P$. cinnamomi sporangia was examined in three repeated trials of this experiment, using eight petri plates containing $15 \mathrm{ml}$ of each soil extract per treatment. The 1:100 (wt/vol) soil extracts were made from nonsterile tap water and unamended soil, soil amended with $1 \%$ gypsum, or soil amended with 5\% gypsum. Two-day-old mycelial mats of $P$. cinnamomi were placed in soil extract and placed under fluorescent lights for 2 days to induce sporangial formation. Mats were treated as previously described to induce zoospore release and zoospore and sporangial production, and volume was determined as above.

The effect of irrigation with various solutions on sporangia production and size and zoospore production was studied in two repeated trials that were conducted on lathhouse benches using eight (2 liter) plastic, drained pots per soil treatment. The soil was not amended with gypsum. Pots were irrigated to container capacity daily for 7 days with tap water, then 2-day-old mycelial mats of $P$. cinnamomi in slide mounts were buried in the soil. Soil was watered to container capacity after the mats were added with one of four solutions: tap water, tap water with dissolved gypsum at $2 \mathrm{~g} /$ liter, distilled water, or distilled water with dissolved gypsum at 2 g/liter. Distilled water was observed to infiltrate very poorly into soil; consequently it was used as an irrigation treatment to simulate poor drainage. The irrigation treatment of distilled water with gypsum provided a high-calcium, slow infiltration rate treatment. Mats were irrigated with the four solutions again on the second day and removed from the soil after 3 days and rinsed with sterile distilled water. Zoospore and sporangial production and sporangial volume were measured as described above.

Effect of different calcium salt amendments on zoospore production. Two repeated trials were conducted in the laboratory using eight 25 -mm-deep petri plates per treatment filled with $100 \mathrm{~g}$ of field soil. Petri plates were perforated on the bottom with 16 holes for water drainage. The soil was amended with $1 \%$ (wt/wt) calcium carbonate $\left(\mathrm{CaCO}_{3}\right), 1 \%$ (wt/wt) calcium nitrate $\left(\mathrm{Ca}\left(\mathrm{NO}_{3}\right)_{2}\right), 5 \%$ (wt/wt) $\mathrm{Ca}\left(\mathrm{NO}_{3}\right)_{2}, 1 \%$ (wt/wt) gypsum, $5 \%$ (wt/wt) gypsum, or was not amended. Two-day-old mycelial mats of $P$. cinnamomi in slide mounts were buried in the soil, which was then watered to container capacity. Water $(25 \mathrm{ml})$ was added at days 2 and 4 after the mats were added, and the slide mounts were removed from the soil on day 5. Viable zoospores were quantified as described above.

Zoospore motility and attraction to host roots. This experiment was carried out in petri plates filled with $15 \mathrm{ml}$ of field soil extract $(1: 100 \mathrm{wt} / \mathrm{wt})$ that was amended with either 6 or $12 \mathrm{mM}$ calcium, and was repeated. Root tips from Persea indica, an avocado species very susceptible to $P$. cinnamomi, were cut into $3-\mathrm{cm}$ lengths. The cut ends of the root segments were sealed with molten paraffin, and the root segments were then placed in the soil extracts. Mycelial mats containing P. cinnamomi sporangia were incubated with $100 \mathrm{ppm}$ of fluorescein diacetate for $3 \mathrm{~h}$ before zoospores were induced to release. A 5-ml aliquot of the quantified, fluorescent zoospore suspension was added to each petri plate containing three root segments and incubated at room temperature for $1 \mathrm{~h}$. The roots were then removed from the soil extract, rinsed with tap water, and examined by fluorescent microscopy (Zeiss Axioplan microscope, Zeiss, West Germany) for the presence of fluorescing zoospore cysts on the root tips. Cysts on each root tip were counted.

Zoospore encystment and passive movement through soil. Three repeated trials in this experiment were conducted in five soil columns per treatment. The soil columns were $30-\mathrm{ml}$ plastic syringe barrels filled with $7 \mathrm{~g}$ of dry field soil (unamended or amended with 5\% gypsum). Ten milliliters of tap water was poured through the soil daily over a 7-day period. The soil was wetted to container capacity, and $5 \mathrm{ml}$ of a quantified $P$. cinnamomi zoospore suspension was added to the top of the soil and allowed to drain completely into the soil column. Three grams of soil were sampled: $1 \mathrm{~g}$ from the soil surface, $1 \mathrm{~g}$ from halfway down the column (approximately $4 \mathrm{~cm}$ ), and $1 \mathrm{~g}$ at the bottom of the soil column (approximately $8 \mathrm{~cm}$ ). The soil was diluted 1:10 in sterile distilled water, and $100 \mu \mathrm{l}$ of the suspension was plated onto PARPH agar. After the suspensions were plated, 1 $\mathrm{ml}$ of $1 \%$ Tween 20 was added to each of the dilutions to lyse swimming zoospores, while leaving encysted zoospores intact; then $100 \mu \mathrm{l}$ was again plated out. The resulting $P$. cinnamomi colonies were counted after 2 to 3 days of growth.

\section{RESULTS}

Frequency and size of sporangia and zoospore production. Sporangial production from mycelial mats was significantly decreased in soil amended with gypsum in greenhouse experiments (Table 1). Calculated sporangial volume was reduced by an average of $64 \%$ by gypsum soil amendments (Table 1). There was no difference among treatments in the percentage of sporangia that were differentiated or released in any of the trials. Fewer colonies were formed in the gypsum-amended soil than in the unamended soil; however, zoospore release was sporadic and colony formation of $P$. cinnamomi on PARPH was highly variable within treatments. No significant treatment differences in colony formation were observed. Zoospores within the sporangia did not differ in size regardless of the size of the sporangia. 
When soil extracts from gypsumamended soils were tested, sporangia production significantly decreased, as was seen in experiments where the mycelial mats were buried in gypsum-amended soil. The average calculated volume of sporangia grown in soil extracts of 1 or 5\% gypsum-amended soil was reduced an average of $48 \%$ (Table 2). Zoospore production from mats grown in soil extracts of 1 and $5 \%$ gypsum-amended soil was also significantly reduced over mats grown in a soil extract from unamended soil (Table 2).

Irrigation with various gypsum solutions of mycelial mats buried in unamended soil also had an effect on sporangia production, sporangial dimensions, and zoospore production. Data from these two trials were not combined since they were significantly different in regard to total volume. The breakdown between treatments was similar. The distilled water treatment had the highest sporangial production and size, and the tap water and gypsum treatment had the lowest production and size in both trials (Figs. 1 and 2). Sporangial production and size were more strongly correlated with presence or absence of gypsum than with type of water used. The addition of gypsum at $2 \mathrm{~g}$ per liter of distilled water, which drained poorly compared with both tap water treatments, decreased sporangial production by $33 \%$ compared with irrigation with distilled water alone. Zoospore release was sporadic, and colony formation was variable among the trials and treatments; there were no significant differences.

Effect of different calcium salt amendments on zoospore production. All calcium treatments significantly decreased the number of zoospores produced in comparison with the unamended soil. The largest reduction was in the $5 \%$ calcium nitrate treatment, but all calcium treatments reduced zoospore production by more than half. Zoospore production in the $1 \%$ gypsum treatment was decreased $78 \%$ over the unamended soil, and the number of zoospores was decreased $74 \%$ in the $5 \%$ gypsum treatment (Table 3).

All calcium treatments reduced the number of colonies formed from zoospores on PARPH. However, the number of swimming zoospores was decreased by $78 \%$ in the $1 \%$ gypsum treatment, but the number of colonies was only decreased by $39 \%$ (Table 3). The soil $\mathrm{pH}$ was not significantly affected by any of the amendments.

Zoospore motility and attraction to host roots. Zoospore motility through a soil extract to root segments of $P$. indica was unaffected by the addition of gypsum to the soil extract.

Zoospore encystment and passive movement through soil. Most zoospores, as measured by colonies formed on selective media, were found in the top $1-\mathrm{cm}$ sample of both gypsum-amended and una- mended soil. Both treatments had the same overall pattern of distribution, with most zoospores found in the top 1-cm sample and the least number found at the bottom

of the soil column. The difference between treatments was not statistically significant. Fewer zoospores in the gypsum-amended soil columns encysted compared with the

Table 2. Influence of soil extracts from gypsum-amended soil on the number and volume of sporangia and number of zoospores (expressed as colonies on PARPH medium) in two repeated trials

\begin{tabular}{|c|c|c|c|c|c|c|}
\hline \multirow[b]{2}{*}{ Amendment ${ }^{y}$} & \multicolumn{2}{|c|}{ Sporangia per $\mathbf{m l}$} & \multicolumn{2}{|c|}{$\mathbf{S V}^{\mathbf{y}}$} & \multicolumn{2}{|c|}{ Zoospores $^{\mathrm{y}}$} \\
\hline & Trial 1 & Trial 2 & Trial 1 & Trial 2 & Trial 1 & Trial 2 \\
\hline Control & $1,261 \mathrm{a}^{\mathrm{z}}$ & $1,382 \mathrm{a}$ & $8.4 \times 10^{5} \mathrm{a}$ & $1.5 \times 10^{6} \mathrm{a}$ & $451 \mathrm{a}$ & $222 \mathrm{a}$ \\
\hline $1 \%$ gypsum & $1,042 \mathrm{ab}$ & $772 \mathrm{~b}$ & $3.9 \times 10^{5} \mathrm{~b}$ & $8.1 \times 10^{5} b$ & $353 \mathrm{ab}$ & $166 \mathrm{ab}$ \\
\hline $5 \%$ gypsum & $820 \mathrm{~b}$ & $627 \mathrm{~b}$ & $5.6 \times 10^{5} \mathrm{~b}$ & $7.2 \times 10^{5} \mathrm{~b}$ & $283 \mathrm{~b}$ & $129 \mathrm{~b}$ \\
\hline
\end{tabular}

${ }^{\text {y }} \mathrm{SV}=$ sporangial volume $\left(\mu \mathrm{m}^{3}\right)$. Zoospores = number of zoospores per ml. Control $=$ soil extract from unamended soil. $1 \%$ gypsum = soil extract from $1 \%$ gypsum-amended soil. $5 \%$ gypsum $=$ soil extract from $5 \%$ gypsum-amended soil.

z Values represent the mean of eight replications per treatment in each trial. Means followed by the same letters are not significantly different according to the Waller Duncan Bayesian $t$ test at $P \leq 0.05$.

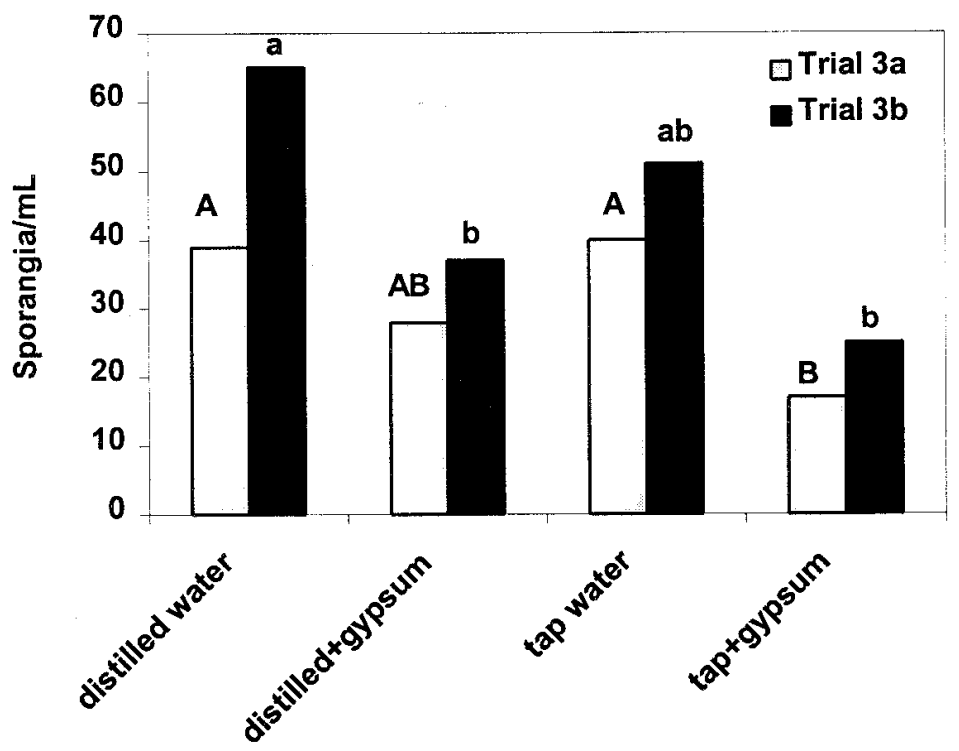

Irrigation solution

Fig. 1. Effect of irrigation with gypsum solutions on number of sporangia produced in uninfested field soil in pots. Mean separations for the first trial (trial 3a) are designated by uppercase letters and for the second trial (trial 3b), by lowercase letters. Values represented by bars with the same letters are not significantly different $(P \leq 0.05)$ according to the Waller-Duncan Bayesian $k$-ratio $t$ test.

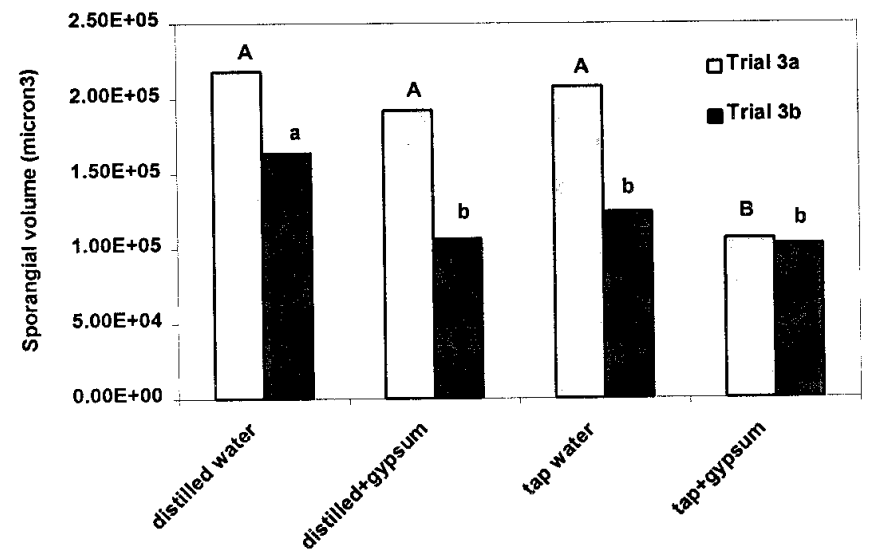

Irrigation solution

Fig. 2. Effect of irrigation with gypsum solutions on sporangial volume produced in uninfested field soil in pots. Mean separations for the first trial (trial 3a) are designated by uppercase letters and for the second trial (trial 3b), by lowercase letters. Values represented by bars with the same letters are not significantly different $(P \leq 0.05)$ according to the Waller-Duncan Bayesian $k$-ratio $t$ test. 
unamended soil columns, but due to variability, the difference was not statistically significant.

\section{DISCUSSION}

Gypsum soil amendments have significant effects on some aspects of the asexual reproduction of $P$. cinnamomi, notably on the production and dimensions of the sporangia formed. The effects of high levels of soluble calcium on sporangial production can be observed in axenic solutions (12), as well as in extracts $(15,16)$. Anions of the calcium salt seem to have little effect on sporangial production, with the same decrease in sporangial production seen in calcium chloride solutions (12), soil extract amended with calcium nitrate $(16,21)$, and soil amended with calcium sulfate (15). These results were verified and expanded on in this study. The reduction in sporangial dimensions in gypsum-amended soil, in addition to the decrease in total number of sporangia, corresponded with a decrease in the number of zoospores produced. The individual zoospores inside the smaller sporangia did not vary in diameter when compared with those inside the larger sporangia; hence the cause of lowered zoospore production appears to be related to both reduced sporangial number and decrease in sporangial dimensions.

Reduction in sporangial size associated with the presence of calcium has not previously been reported in either axenic solutions or soil extracts. Sporangial differentiation and zoospore release did not appear to be affected by gypsum in the soil, although zoospore release was often sporadic. This variability in zoospore release may be due to immature sporangia, since the mats were only left in the soil for 2 days. In a previous study, mycelial mats grown in a soil extract with calcium nitrate showed an inhibition of zoospore release (16) that we did not observe in our study. Although poor drainage is closely linked to increased disease due to Phytophthora root rot in avocados, when we irrigated infested soil with a high calcium, low soil infiltration solution, we observed a decrease in sporangial number and size. The presence of the calcium adversely affected the pathogen despite favorable growth conditions.

Table 3. Zoospore production and colony formation from mats grown in soil amended with different calcium salts in two laboratory trials

\begin{tabular}{lccc}
\hline Soil amendment & Zoospores/ml & CFU $^{\mathbf{y}}$ & Soil pH \\
\hline Unamended & $3,301 \mathrm{a}^{\mathrm{z}}$ & $232 \mathrm{a}$ & $6.42 \mathrm{a}$ \\
$1 \% \mathrm{CaCO}_{3}$ & $980 \mathrm{~b}$ & $165 \mathrm{~b}$ & $6.90 \mathrm{a}$ \\
$1 \% \mathrm{Ca}\left(\mathrm{NO}_{3}\right)_{2}$ & $1,077 \mathrm{~b}$ & $5 \mathrm{e}$ & $5.86 \mathrm{a}$ \\
$5 \% \mathrm{Ca}\left(\mathrm{NO}_{3}\right)_{2}$ & $87 \mathrm{c}$ & $22 \mathrm{de}$ & $5.54 \mathrm{a}$ \\
$1 \%$ gypsum & $682 \mathrm{bc}$ & $75 \mathrm{c}$ & $6.40 \mathrm{a}$ \\
$5 \%$ gypsum & $796 \mathrm{~b}$ & $60 \mathrm{~cd}$ & $6.39 \mathrm{a}$ \\
\hline
\end{tabular}

y $\mathrm{CFU}=$ colony-forming units of Phytophthora cinnamomi on PARPH medium.

${ }^{\mathrm{z}}$ Values represent the mean of eight replications from two trials that did not differ significantly. Means in each column followed by the same letters are not significantly different $(P \leq 0.05)$ as indicated by the Waller-Duncan Bayesian $k$-ratio $t$ test. ble in water; whereas gypsum, the form of calcium used in our studies, has low solubility. Ionic calcium in extracts from gypsum-amended soil was at most $5 \mathrm{mM}$ and, with the other factors that cause encystment in soil, could explain the failure of the gypsum-amended soil to affect zoospore encystment.

Gypsum amendments to a California avocado soil reduced sporangial production, sporangial size, and zoospore production. The suppressive effect was also observed in vitro with soil extracts made from the gypsum-amended soil and when unamended soil was irrigated with a gypsum solution. The gypsum amendments had little or no effect on zoospore motility or encystment. The mechanism for the observed decrease in avocado root rot with gypsum soil amendments seems to focus mainly on the effects on $P$. cinnamomi. Gypsum soil amendments could be further tested for their ability to decrease avocado root rot in an avocado grove as an inexpensive and safe alternative or addition to fungicidal control methods.

\section{LITERATURE CITED}

1. Ayers, W. A., and Zentmyer, G. A. 1971. Effect of soil solution and two soil pseudomonads on sporangium production by $P h y-$ tophthora cinnamomi. Phytopathology 61:1188-1193.

2. Broadbent, P., and Baker, K. F. 1974. Behavior of Phytophthora cinnamomi in soils suppressive and conducive to root rot. Aust. J. Agric. Res. 25:121-137.

3. Byrt, P. N., Irving, H. R., and Grant, B. R. 1982. The effects of cations on zoospores of the fungus Phytophthora cinnamomi. J. Gen. Microbiol. 128:1189-1198.

4. Casale, W. L., Minassian, V., Menge, J. A., Lovatt, C. J., Pond, E., Johnson, E., and Guillemet, F. 1995. Urban and agricultural wastes for use as mulches on avocado and citrus and for delivery of microbial biocontrol agents. J. Hortic. Sci. 70:315-332.

5. Coffey, M. D. 1987. Phytophthora root rot of avocado: An integrated approach to control in California. Plant Dis. 71:1046-1052.

6. Donaldson, S. P., and Deacon, J. W. 1993 Changes in motility of Pythium zoospores induced by calcium and calcium-modulating drugs. Mycol. Res. 97:877-883.

7. Gees, R., and Coffey, M. D. 1989. Evaluation of a strain of Myrothecium roridum as a potential biocontrol agent against Phytophthora cinnamomi. Phytopathology 79:1079-1084.

8. Gilbert, G. S., Handelsman, J., and Parke, J. L. 1990. Role of ammonia and calcium in lysis of zoospores of Phytophthora cactorum by Bacillus cereus strain UW85. Exp. Mycol. 14:1-8.

9. Grant, B. R., Irving, H. R., and Radda, M. 1985. The effect of pectin and related compounds on encystment and germination of Phytophthora palmivora zoospores. J. Gen. Microbiol. 131:669-676.

10. Griffith, J. M., Iser, J. I., and Grant, B. R. 1988. Calcium control of differentiation in Phytophthora palmivora. Arch. Microbiol. 149:565-571.

11. Gubler, F., Hardham, A. R., and Duniec, J. 1989. Characterizing adhesiveness of Phytophthora cinnamomi zoospores during encystment. Protoplasma 149:24-30.

12. Halsall, D. M., and Forrester, R. I. 1977. Effects of certain cations on the formation 
and infectivity of Phytophthora zoospores. 1. Effects of calcium, magnesium, potassium and iron ions. Can. J. Microbiol. 23:994-1001.

13. Irving, H. R., and Grant, B. R. 1984. The effect of calcium on zoospore differentiation in Phytophthora cinnamomi. J. Gen. Microbiol. 130:1569-1576.

14. Labanauskas, C. K., Nauer, E. M., and Roistacher, C. N. 1967. Initial soil mix and postplanting liquid fertilization effects on nutrient concentration in Valencia orange seedling leaves. Hilgardia 38:569-577.

15. Lee, B. S. 1979. The influence of calcium and nitrogen on diseases caused by Phytophthora cinnamomi and two morphological forms of Phytophthora palmivora. Ph.D. diss. University of California, Riverside.

16. Lee, B. S., and Zentmyer, G. A. 1982. Influence of calcium nitrate and ammonium sulfate of Phytophthora root rot of Persea indica. Phytopathology 72:1558-1564.

17. MacDonald, J. D., and Duniway, J. M. 1978. Influence of soil texture and temperature on the motility of Phytophthora cryptogea and $P$. megasperma zoospores. Phytopathology 68:1627-1630.

18. Messenger-Routh, B. J., Menge, J. A., and Pond, E. C. 1996. Effect of gypsum soil amendments on avocado root rot. (Abstr.)
Phytopathology 86:S30.

19. Tay, F. C. S., Nandapalan, K., and Davison, E. M. 1983. Growth and zoospore germination of Phytophthora spp. on $\mathrm{P}_{10} \mathrm{VP}$ agar with hymexazol. Phytopathology 73:234-240.

20. Trochoulias, T., Broadbent, P., and Baigent, D. R. 1986. Response of avocado to calcareous and organic amendments. Acta Hortic. 175:179-181.

21. Tsao, P. H., and Zentmyer, G. A. 1979. Suppression of Phytophthora cinnamomi and Phytophthora parasitica in urea amended soil. Pages 191-199 in: Soil-borne Plant Pathogens. B. Schippers and W. Gams, eds. Academic Press, New York. 